\title{
INHERITING MADNESS
}




\section{Medicine and Society Andrew Scull, Editor}

This series examines the development of medical knowledge and psychiatric practice from historical and sociological perspectives. The books contribute to a scholarly and critical reflection on the nature and role of medicine and psychiatry in modern societies.

1. Robert Castel, The Regulation of Madness: Origins of Incarceration in France. Translated by W. D. Halls.

2. John R. Sutton, Stubborn Children: Controlling Delinquency in the United States, 1640-1981.

3. Andrew Scull, Social Order/Mental Disorder: Anglo-American Psychiatry in Historical Perspective.

4. Ian R. Dowbiggin, Inheriting Madness: Professionalization and Psychiatric Knowledge in Nineteenth-Century France. 


\title{
INHERITING MADNESS
}

\author{
Professionalization and \\ Psychiatric Knowledge in \\ Nineteenth-Century France
}

IAN R. DowbigGin

University of California Press

Berkeley Los Angeles Oxford 
This book is a print-on-demand volume. It is manufactured using toner in place of ink. Type and images may be lcss sharp than the same matcrial seen in traditionally printed University of California Press editions.

University of California Press

Berkeley and Los Angeles, California

University of California Press, Ltd.

Oxford, England

(C) 1991 by

The Regents of the University of California

\section{Library of Congress Cataloging-in-Publication Data}

Dowbiggin, Ian R.

Inheriting madness : professionalization and psychiatric knowledge in nineteenth-century France / Tan R. Dowbiggin. p. $\quad \mathrm{cm} . \quad$ - (Medicine and society)

Includes bibliographical references.

ISBN 0-520-06937-4

1. Psychiatry-France-History - 19th century

2. Mental illness-France-History--19th century.

I. Title. II. Series.

RC450.F7D68 1991

616 89'00944'09034- de20 90-10914

CIP

Printed in the United States of America

The paper used in this publication meets the minimum requirements of American National Standard for Information Sciences-Permanence of Paper for Printed Library Materials, ANSI Z39.48-1984. @) 
To Terry and her love of the world of ideas 
This page intentionally left blank 